\title{
Devonian plants from Colombia, with discussion of their geological and palaeogeographical context
}

\author{
CHRISTOPHER M. BERRY*, EDUARDO MOREL $\uparrow$, JAIRO MOJICA $†$ \\ \& CARLOS VILLARROEL \\ * Department of Earth Sciences, University of Wales Cardiff, P. O. Box 914, Cardiff CF10 3YE, Wales, UK \\ †Departamento de Paleobotánica, Museo de la Plata, Paseo del Bosque s/m, 1900 La Plata, Argentina \\ †Universidad Nacional de Colombia, Departamento de Geociencias, Apartado 14490, Bogotá, Colombia
}

(Received 24 June 1999; accepted 25 January 2000)

\begin{abstract}
Plant fossils are described from the Cuche Formation, Eastern Cordillera, Colombia in the area of Floresta. Those identified as Colpodexylon cf. deatsii Banks and cf. Archaeopteris sp. suggest an earliest Late Devonian (Frasnian) age for the formation. These or similar taxa are also found in contemporaneous deposits in western Venezuela, and other elements of the Venezuelan flora are found in a geographically intermediate locality. All three Devonian plant localities in the northwest of South America are within the Colombian Eastern Cordillera and its northern extension, the Venezuelan Perijá Range, an area that has been integrated as a part of the so-called 'Eastern Andean Terrane' or 'Central Andean Province', supposedly accreted to the autochthonous block of the Guyana Shield during the early Jurassic or before. Although both invertebrates and plants from this terrane have strong affinities to North American and European assemblages, and might be interpreted as implying a Laurussian origin for the Eastern Andean Terrane, the evidence is not yet unequivocal, with some authors postulating an in situ development of this province.
\end{abstract}

\section{Introduction}

Records of vascular plants are rare in Devonian sediments of South America. The most comprehensive reports have been from the Middle and Upper Devonian of western Venezuela (Berry, Edwards and co-authors) and the Silurian/Lower Devonian of Bolivia/Argentina (Morel, Edwards \& Iñigez Rodriguez, 1995). This scarcity of fossil evidence has frustrated attempts at global phytogeography during these times (Edwards \& Berry, 1991).

The present report concerns fossil plants from Devonian strata of the Cuche Formation, outcropping in the Eastern Cordillera, Colombia around Floresta in the Department of Boyacá (Figs 1, 2), and is complimentary to work on fossil vertebrates in the same region (Janvier \& Villarroel, 1998).

The field observations and collection of the samples were accomplished by $\mathrm{JM}$ and $\mathrm{CV}$, further samples collected by Professor Medardo Chacón, and study of the fossil plants was undertaken by CMB and EM.

\section{Geological background and localities}

As shown in the publications of Barrett (1988) and Forero (1991), known outcrops of sedimentary Devonian rocks in Colombia are completely restricted to a region comprising the Eastern Cordillera, its northward extension in the Sierra de Perijá and the upper Magdalena Valley. However, the Devonian

* Author for correspondence: berrycm@cardiff.ac.uk exposures (for the most part Middle Devonian) are sparse within this area, and occur generally in massifs with Precambrian to ?Early Palaeozoic crystalline cores. The Floresta Massif is composed of a crystalline core unconformably covered by Devonian sediments that include the El Tibet, Floresta and Cuche formations. The El Tibet Formation has a restricted distribution and thickness ranging up to $425 \mathrm{~m} \mathrm{(M.} \mathrm{G.}$ Paz \& A. D. Urrutia, unpub. Trabajo de Grado, Departamento de Geociencias, Universidad Nacional de Colombia, Bogotá, 1996). It is composed mainly of fine- to coarse-grained quartzitic and kaolinitic sandstones, deposited essentially in a continental environment (braided streams) and coastal to subcoastal conditions. On the basis of a spore assemblage, Grösser \& Prössel (1994) defined an Emsian age for this unit.

The overlying Floresta Formation (Olsson \& Caster, 1939) contains fossil invertebrates (brachiopods, trilobites, bryozoans, gastropods, etc.) as described by Caster (1939), Royo y Gómez (1942), Morales (1965), and fish remains of rhenanid and arthrodire type (Janvier \& Villarroel, 1998). The fossil content indicates a Middle Devonian age for the Floresta Formation.

The Cuche Formation (Botero, 1950) is the youngest of the Palaeozoic sedimentary sequences developed in the Floresta Massif. It represents a regressive unit deposited in a transitional environment that includes tidal to supratidal sandstones (Lower Member) and lagoonal siltstones containing a fossil assemblage of vertebrates, invertebrates and plants 


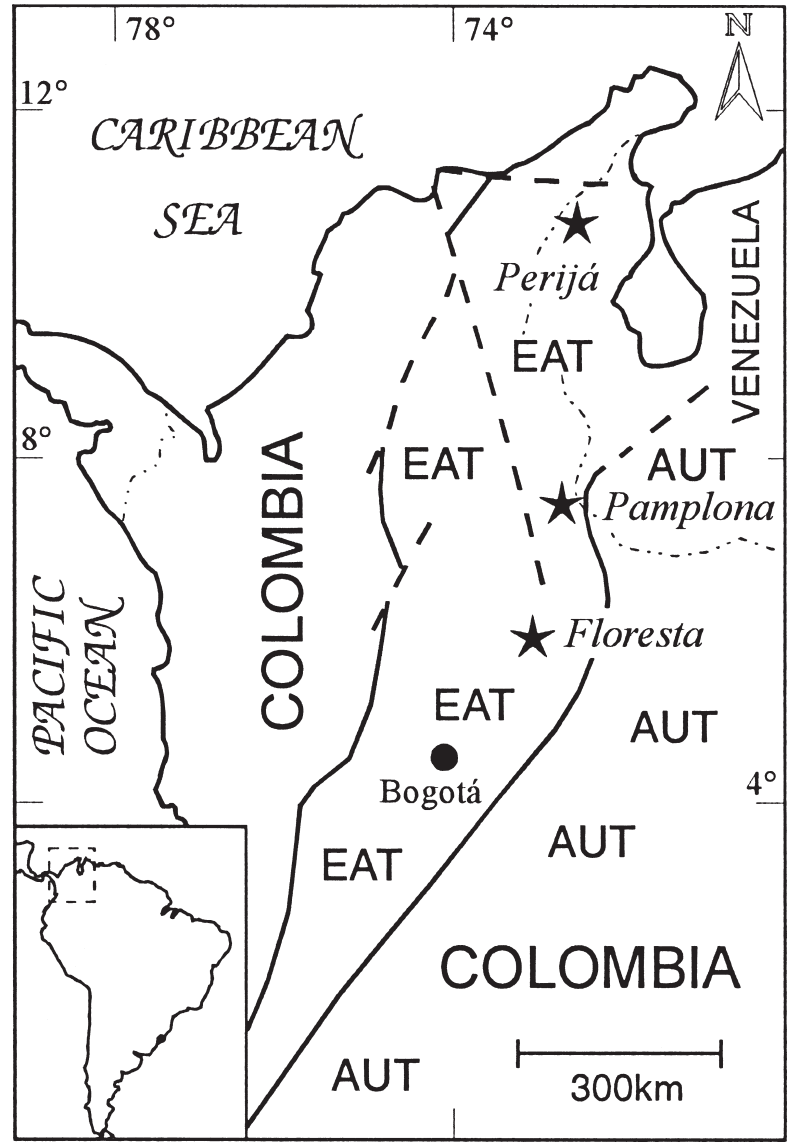

Figure 1. Devonian outcrops yielding fossil plants in Colombia and northwestern Venezuela (stars) in relation to selected terranes. AUT = Autochthonous Terrane (Guyana Shield), EAT $=$ Eastern Andean Terrane (including Sierra de Perijá and Eastern Cordillera). Modified from Restrepo \& Toussaint, 1988.

which reflect the transition from typical shallow marine conditions to a nearshore terrestrial domain. This unit is made up of beds of sandstones and siltstones, which have a concordant and transitional relationship with the underlying Floresta Formation. It consists of a Lower Member $(140 \mathrm{~m})$ of sandstones and an Upper Member $(250 \mathrm{~m})$ in which there are thick beds of red, violet and ochre sandstones and siltstones. The Lower Member contains many small, unidentifiable fragmentary plant remains, but the Upper Member contains several beds with well-preserved fossil plants. The depositional environment has been interpreted as shallow water, of varying energy, with occasional subaerial exposure (Mojica \& Villarroel, 1984). The Cuche Formation is overlain discordantly by a thick sequence of red beds (conglomerates, sandstones and siltstones) resembling the Upper Jurassic Girón Formation (Hettner, 1892). After the deposition of the Cuche Formation and before the accumulation of the Girón-like red beds, the Floresta Massif was uplifted leading to no deposition or erosion of the Carboniferous and Permian sequences

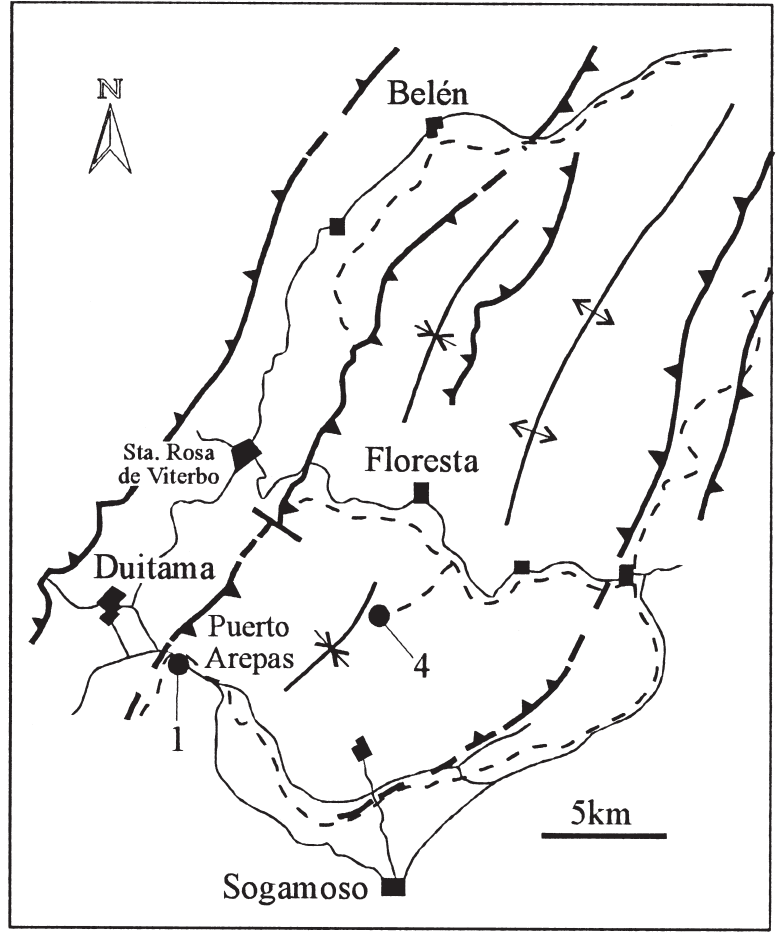

Figure 2. Location map of the two fossil localities mentioned in this report: (1) Puerto Arepas; (4) Quebrada Potrero Rincón. Modified after Mojica \& Villarroel, 1984.

known in the adjoining Santander Massif, studied in detail by Rabe (1977).

Mojica \& Villarroel (1984) provided a list of plant fossils from the Cuche Formation, including the genera Psilophyton Dawson emend. Banks, Leclercq \& Hueber and Ginkgophyton sensu Beck. Other fossils include the ostracod Welleria Ulrick \& Bassler and fish remains. On this basis Mojica \& Villarroel (1984) assigned an age from Middle Devonian to Early Carboniferous to the Cuche Formation. However, recent study of the vertebrate fauna has allowed restriction of the time of deposition to the Late Devonian Epoch, specifically to the Frasnian (Janvier \& Villarroel, 1998).

The plant fossils studied in this paper include the same specimens reported by Mojica \& Villarroel (1984) as well as others, collected later by JM and CV.

The fossils described here were collected near Floresta, in the Eastern Cordillera (Fig. 1). Most derive from the section through the upper part of the Floresta Formation and the Cuche Formation in the upper part of Quebrada Potrero Rincón (Fig. 2, locality 4) described by Mojica \& Villarroel (1984, their figs $3,4)$. A complimentary stratigraphic section was provided by Janvier \& Villarroel (1998, their fig. 2). The best preserved and most informative plant specimens are from assemblage III (Mojica \& Villarroel, 1984, their fig. 3), derived from a locality made up of sandy shales of a yellow/brown colour which also contain 
fish scales and bones (Janvier \& Villarroel, 1998, locality PR-1). Plant fossils include the specimen of Colpodexylon, the unnamed trimerophyte derivative, cf. Archaeopteris and some of the leafy fossils. The horizon is in the middle of the Upper Member of the Cuche Formation.

A single large leaf, Mch-019-e, was recovered from the same section in Quebrada Potrero Rincón, towards the bottom of the Lower Member, where rain drop impressions ('gotas de lluvia') are recorded just below thick beds of reddish sandstones (Mojica \& Villarroel, 1984, fig. 3).

Other large leaves have been found in the site named 'Puerto Arepas' on the south side of the road from Duitama to Sogamoso, just below an angular unconformity with the conglomerates of the Early Cretaceous Tibasosa Formation. This locality is marked as 1 on Figure 2. These fossils are preserved in red micaceous sandstone.

\section{Methods}

Plant megafossils were uncovered using needles (dégagement: Fairon-Demaret, Hilton \& Berry, 1999). They were photographed using a Canon F-1 camera, macro lens and extension tubes where necessary. All photographs were taken dry using crossed polarizing filters to enhance contrast. Palynological preparations using standard techniques showed the matrix to be barren of palynomorphs.

The fossils are retained in the collections of the Departamento de Geociencias, Bogotá.

\section{Palaeobotanical descriptions}

\section{Colpodexylon cf. deatsii Banks Figures 3a-d, 4}

Material. Specimen no. CCHE-IX-86-023; locality 4, assemblage III.

Stem morphology. The stem is $36 \mathrm{~mm}$ long and $9.3 \mathrm{~mm}$ in exposed width (Fig. 3a), although it appears not to be completely preserved on the right-hand side. It is preserved as an impression, with a small amount of organic material remaining. The stem surface is dark brown in colour. Leaf attachments are represented by inverted vshaped depressions arranged in more or less flat rows separated by a distance of approximately $1.6 \mathrm{~mm}$. Leaf bases alternate in successive gyres. Leaf bases are also visible on the left-hand margin of the stem where they are thickened compared to the proximal leaf lamina, appearing decurrent in compression beside the stem. At the widest part of the remaining stem there are a maximum of six leaf bases visible in any gyre, implying a minimum of 12 in any complete rotation.

Leaf morphology. A single basal portion of a leaf going down into the matrix below the stem has a width of $1.0 \mathrm{~mm}$. Other examples uncovered compressed beside the stem are much thinner $(0.4-0.6 \mathrm{~mm})$, this being due to compaction and folding of the lamina. Four leaves have been uncovered and are comparatively well preserved. Their measurements are recorded in Table 1. Lengths of leaves and segments are minimum only, as the tips are so delicate it is difficult to uncover them, and most are incomplete. The leaves have a maximum observed length of $21.9 \mathrm{~mm}$. Uncovering the four well-preserved leaves revealed them to be divided. Careful removal of one segment of the fourth leaf (segment 1, Figs 3b-d, 4a,b) revealed two further segments below (segments 2,3). The leaves are therefore trifurcate. A reconstruction is given in Figure $4 \mathrm{~d}$. Two short segments are arranged either side of a medial longer segment. They have acute tips where preserved.

Identity and comparisons. Of the well known species of Devonian herbaceous lycopsids, only Colpodexylon Banks (1944) has leaves which are divided into three segments in such a manner. Literature on this genus was recently reviewed by Berry \& Edwards (1995). Leaves of Minarodendron $(\mathrm{Li}, 1990)$ have three segments of which the central segment is perpendicular to the other two and differs also in that the margins are serrate.

Colpodexylon is well known from the Devonian strata of New York State (Banks, 1944; Grierson \& Banks, 1963). Two species (C. deatsii, C. trifurcatum) were originally distinguished by Banks (1944) on the basis of measurements of leaf and sporangial dimensions. Edwards \& Benedetto (1985) described a new species, C. cachiriense, with shorter leaves and bases which were not contiguous, from western Venezuela. A species with proportionally shorter segments distal to the trifurcation was described by Schweitzer \& Cai (1987) from the Givetian of southwestern

Table 1. Measurements of dimensions (in millimetres) of leaves of Colpodexylon cf. deatsii from Colombia

\begin{tabular}{|c|c|c|c|c|c|c|c|}
\hline Leaf & $\begin{array}{l}\text { Total length } \\
\text { of leaf }\end{array}$ & $\begin{array}{l}\text { Length to } \\
\text { trifurcation }\end{array}$ & $\begin{array}{l}\text { Width below } \\
\text { trifurcation }\end{array}$ & $\begin{array}{c}\text { Length median } \\
\text { segment }\end{array}$ & $\begin{array}{l}\text { Width median } \\
\text { segment }\end{array}$ & $\begin{array}{l}\text { Length lateral } \\
\text { segment(s) }\end{array}$ & $\begin{array}{c}\text { Width lateral } \\
\text { segment(s) }\end{array}$ \\
\hline $\mathrm{a}$ & 21.9 & 12.5 & 0.46 & 9.4 & 0.46 & 2.9 & 0.17 \\
\hline \multirow[t]{2}{*}{$\mathrm{b}$} & & & 0.41 & & 0.31 & 1.65 & 0.15 \\
\hline & & & & & & 2.9 & 0.12 \\
\hline $\mathrm{c}$ & & & 0.39 & & 0.34 & 2.9 & 0.15 \\
\hline d & & & 0.56 & & 0.31 & & 0.17 \\
\hline
\end{tabular}



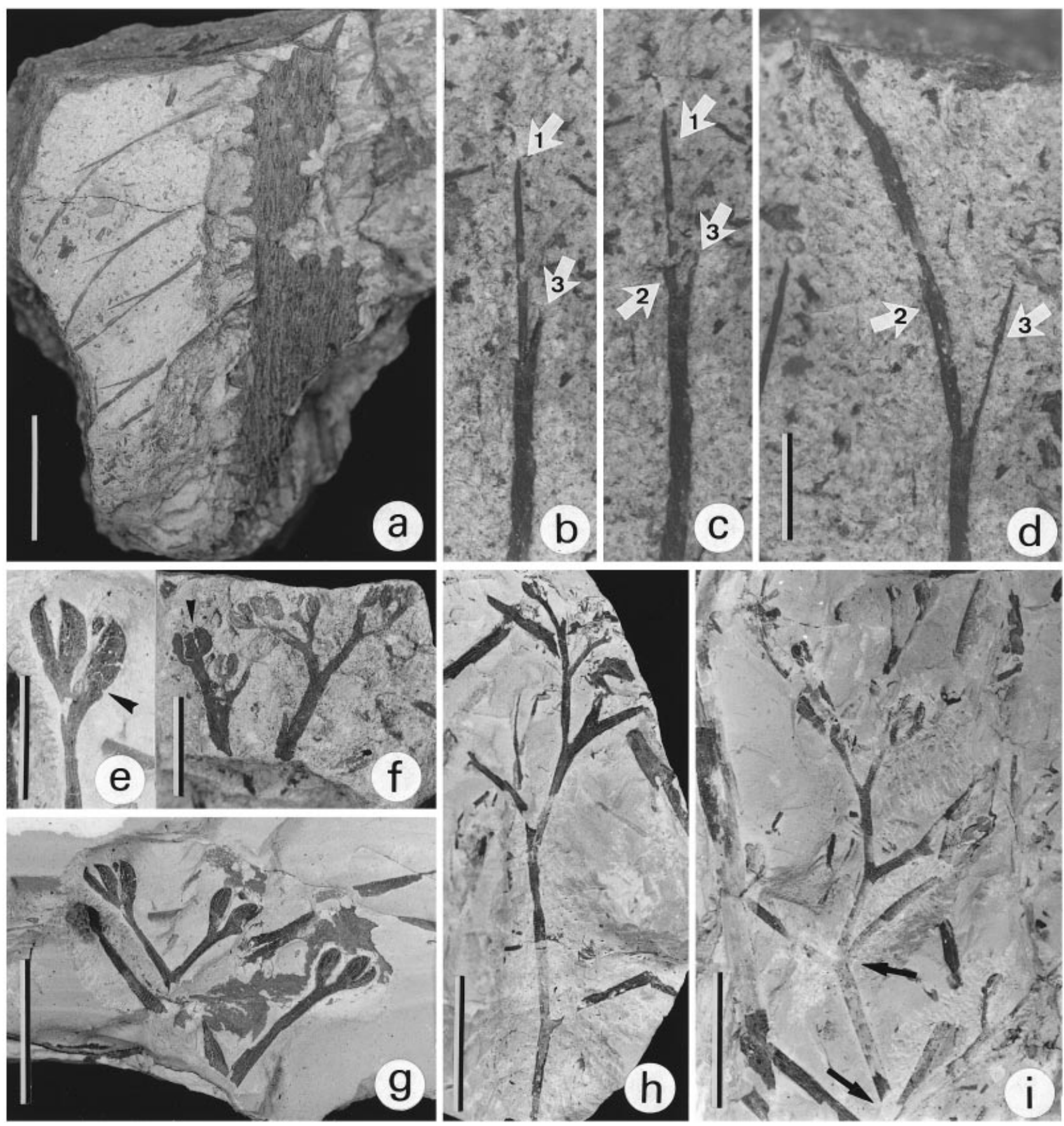

Figure 3. Plant fossils from Quebrada Potrero Rincón. (a-d) Colpodexylon cf. deatsii Banks, CCHE-IX-86-023. (a) View of fossil after extensive dégagement; (b-d) three views of second leaf from top during dégagement showing three distinct segments (1, 2,3). (e-i) Unnamed trimerophyte derivative. (e) Close-up of paired sporangia showing beak and dehiscence line, constriction at base of sporangium (arrowhead), specimen no. ICN-PI-0268-1; (f) fertile terminations of axes with more rounded sporangia probably arranged in pairs (e.g. arrow), unnumbered specimen; (g) fertile termination of axes, specimen no. ICN-PI-0268-1; (h) fertile branching axes, specimen no. ICN-PI-0380-1; (i) fertile branching axes showing bifurcate and trifurcate (arrows) branching, specimen no. ICN-PI-0327. Scale bars: (a) $10 \mathrm{~mm}$, (b-d) $2 \mathrm{~mm}$, (e, f) $5 \mathrm{~mm}$, (g-i) $10 \mathrm{~mm}$.

China. More recently, new species with both short (C. coloradense) and long (C. camptophyllum) distal segments have been described from Venezuela (Berry \& Edwards, 1995).

With only a single fragmentary specimen it is impossible to place it in any one of these species with certainty, and certainly no new species can be erected. However, on the basis of the close arrangement of leaves on the stems and the general leaf morphology it is superficially most similar to $C$. deatsii from New York State, although also close to $C$. trifurcatum. Leaves do not have the same flattened appearance as C. camptophyllum.

Unidentified trimerophyte derivative Figures 3e-i, 5 


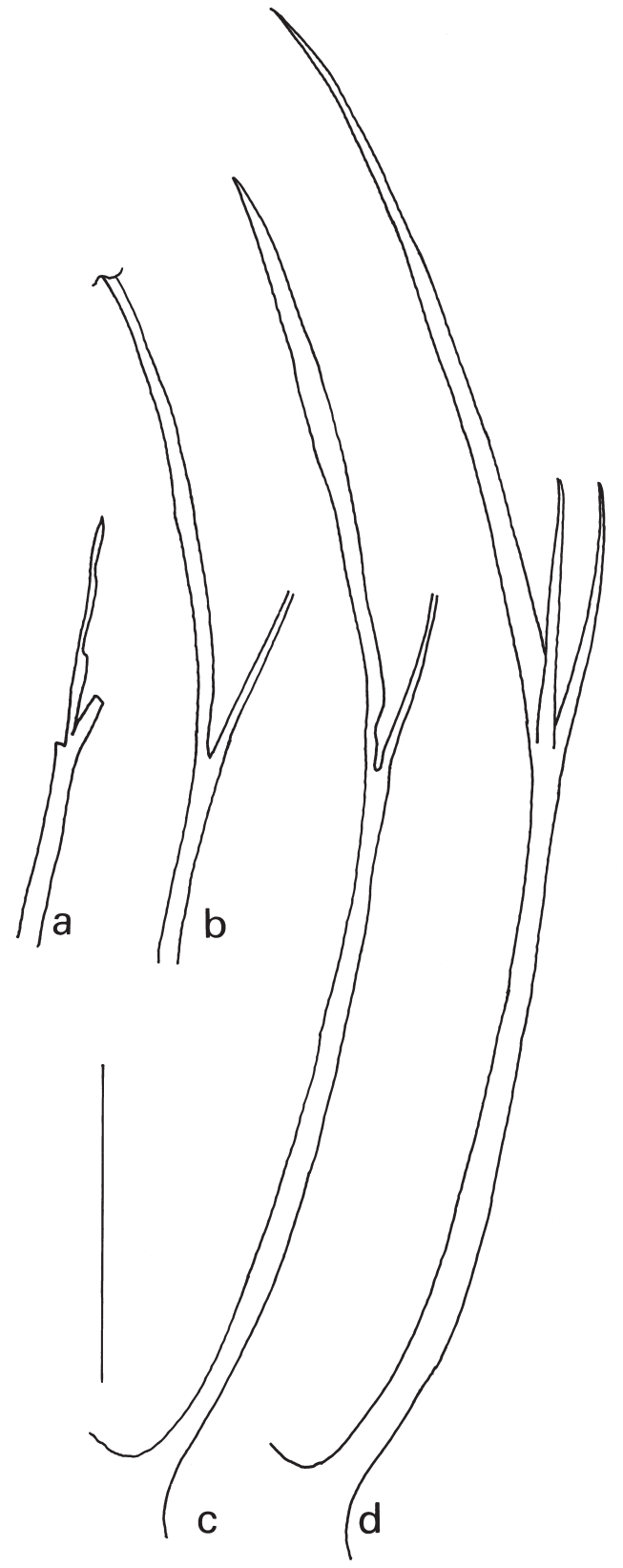

Figure 4. Colpodexylon cf. deatsii Banks, CCHE-IX-86-023. $(\mathrm{a}, \mathrm{b})$ Sequential stages of dégagement of second leaf from top in Figure 3a (see Fig. 3b-d); (c) outline of top leaf in Figure 3a; (d) reconstruction of whole leaf. Scale bar $=5 \mathrm{~mm}$.

Material. Four slabs bear fragments of an as yet unidentified trimerophyte derivative for which, because of a lack of counterparts and of preserved anatomy, it is impossible to make a satisfactory description or make taxonomic deductions. However they probably all belong to the same species. They were previously assigned to Psilophyton and probably P. microspinosum by Petriella (in Mojica \& Villarroel, 1984). Dégagement revealed far more of the branching pattern than had been observed on the surface by previous observers. All these fossils derived from locality 4 , assemblage III.

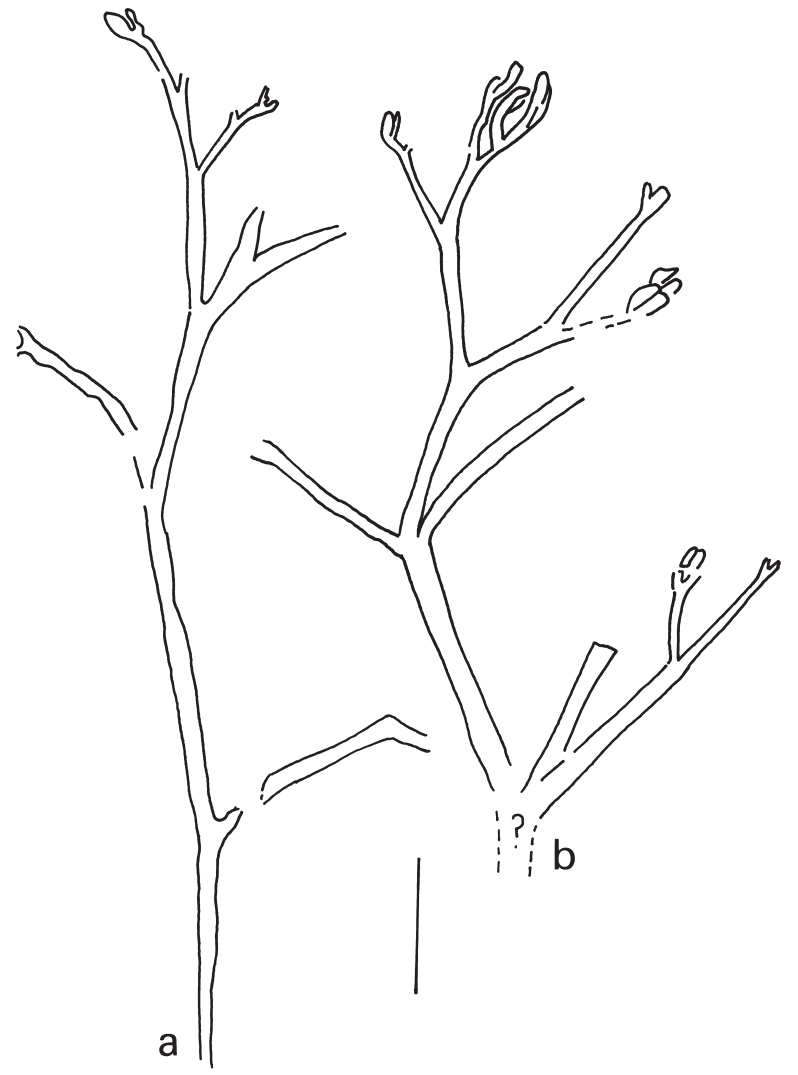

Figure 5. Line drawings of unnamed trimerophyte derivative. (a) ICN-PI-0380-1, (b) ICN-PI-0327 (see Fig. 3h, i). Scale bar $=5 \mathrm{~mm}$.

\section{Specimen no. ICN-PI-0380-1 \\ Figures $3 i, 5 b$}

Basally, there may be a trichotomy of the stem (Fig. 3i, lower arrow), yielding an uncovered branch (central) and a dichotomous branch bearing terminal sporangia (right). The main axis is $1 \mathrm{~mm}$ in diameter and trichotomizes more or less equally to give three $0.6 \mathrm{~mm}$ diameter axes $11 \mathrm{~mm}$ from the base (Fig. 3i, upper arrow). The left-hand axis is not preserved and the right-hand was only partially uncovered. The central axis branches again dichotomously $6 \mathrm{~mm}$ from the previous branching point, and each of the daughter axes dichotomizes further. Beyond this, pairs of terminal sporangia are visible, although their preservation is indistinct, following one or a number of more closely spaced dichotomies.

\section{Specimen no. ICN-PI-0327}

Figures 3h, 5a

This specimen has a maximum length of $41 \mathrm{~mm}$ and is $0.6 \mathrm{~mm}$ in diameter at the base. The distantly spaced basal branching points suggest a monopodial arrangement. Branching is not well-enough preserved to determine if it is dichotomous or trichotomous. 
A number of close dichotomies distally yield paired terminal sporangia.

\section{Specimen no. ICN-PI-0268-1 \\ Figure 3e, g}

Dichotomous axes bear distally terminal sporangia. These are of $2.0-2.8 \mathrm{~mm}$ in length and $0.9-1.2 \mathrm{~mm}$ in width and apparently flattened. The arrangement of the sporangia is not clear with the material to hand. They lie in different orientations and a lack of counterpart prevents meaningful dégagement. The most obvious disposition is that they are arranged in pairs (Fig. 3g, furthest right). Others may contradict this assertion; for example, those in Figure $3 \mathrm{~g}$, top left (enlarged in Fig. 3e) strongly suggest dehiscence has occurred and the valve has broken into two more or less equal halves. It is possible that this second arrangement may take on the appearance of the first if compressed at a different angle. It is also possible that those illustrated in Figure $3 \mathrm{e}$ might represent two sporangia arranged as a pair, with straight margins adjacent and curved outer margins. One sporangium shows a possible constriction in the axis at its base, which may demonstrate a specialized abscission layer (Fig. 3e, arrowhead).

\section{Unnumbered specimen Figure $3 f$}

Two dichotomous trusses lying close together on the slab have several sporangia visible, arranged in pairs with straight margins on the inner face of the pair. The outer margins of the sporangia of this specimen are more strongly convex than in the other examples. The sporangia are $1-1.3 \mathrm{~mm}$ in length and $0.5-0.8 \mathrm{~mm}$ wide.

Discussion and comparisons. Small dichotomizing branched axial plant fossils reminiscent of the Early Devonian trimerophyte genus Psilophyton are commonly found in Middle and lowermost Upper Devonian sediments. They are often attributed to the form genus Psilophytites (Høeg, 1952) when sterile and bearing small spines.

Although the exact disposition of the sporangia (paired or not paired?) remains unresolved, the arrangement in pairs of sporangia in the unnumbered specimen (above) is preferred to a single dehisced sporangium because the single sporangium would have to be globose in order to achieve the morphology pictured after a median dehiscence (Fig. 3f).

The fossils described above are likely to derive from trimerophyte ancestors because of the probably paired terminal sporangia and general morphology typical of this group. No Middle or Upper Devonian plant has been shown to have both morphological and anatomical characteristics of the genus Psilophyton. The latter traits, namely centrach terrete primary xylem strand, pitted tracheids and dichotomous division of the xylem strand into distal branches, are not presently known from Middle Devonian plants. The only Middle Devonian species named Psilophyton, $P$. kräuseli, was established by Obrhel $(1959,1961)$ for a small number of Middle Devonian specimens from Bohemia. The plant is spiny, yet lacks preserved anatomy, and the single fertile specimen is not well enough preserved to demonstrate the exact arrangement of sporangia. Although dichotomous branching prevails in the genus Psilophyton, trifurcate branching is known from Lower Devonian P. dawsonii (Banks, Leclercq \& Hueber, 1975), where sometimes an aborted third trace is present at a branching point. However the alternating nodal angle of the main axis in our largest specimen, giving a zigzag effect, hints at a higher level of anatomical complexity. For example, ribbed primary xylem columns are responsible for an identical zigzag, trifurcate branching pattern in anatomically preserved Stenokoleos holmesii (Matten, 1992). However the morphology of plants in the Stenokoleales remains unknown. Unfortunately our specimens are not large enough to determine if there is a regular and repetitive orientation of the lateral branches as one might expect for a ribbed vascular system of the main stem, or a random orientation that one might expect from a Psilophyton-like anatomical organization.

Unpublished plants with a similar branching pattern are known from Middle or lowermost Upper Devonian assemblages from Venezuela, yet have more complex sporangial clusters reminiscent of aneurophytalean progymnosperms.

\section{cf. Archaeopteris Dawson Figure 6a, b}

Material. These fossils derive from locality 4, assemblage III.

\section{Specimen no. CCHE-IX-86-026 (a) \\ Figure 6a}

Numerous leaves are present on this slab. The most informative are the four inserted on the right-hand margin of an axis $3 \mathrm{~mm}$ wide, spaced $20 \mathrm{~mm}$ apart. The surface of the axis is marked by small transversely oriented ornament. The leaves have narrow bases, are about $33 \mathrm{~mm}$ in length and $20 \mathrm{~mm}$ maximum width, and have an entire margin. They are of an overall flabelliform morphology. Venation is dichotomous, with the distal veins curved away from the midline of the leaf towards the margins. Other fragments on the specimen suggest leaves which were considerably larger. Elongate $1.5 \mathrm{~mm}$ long sporangia are also present, but not in attachment to other organs. Larger stems with a similar ornament are visible. 

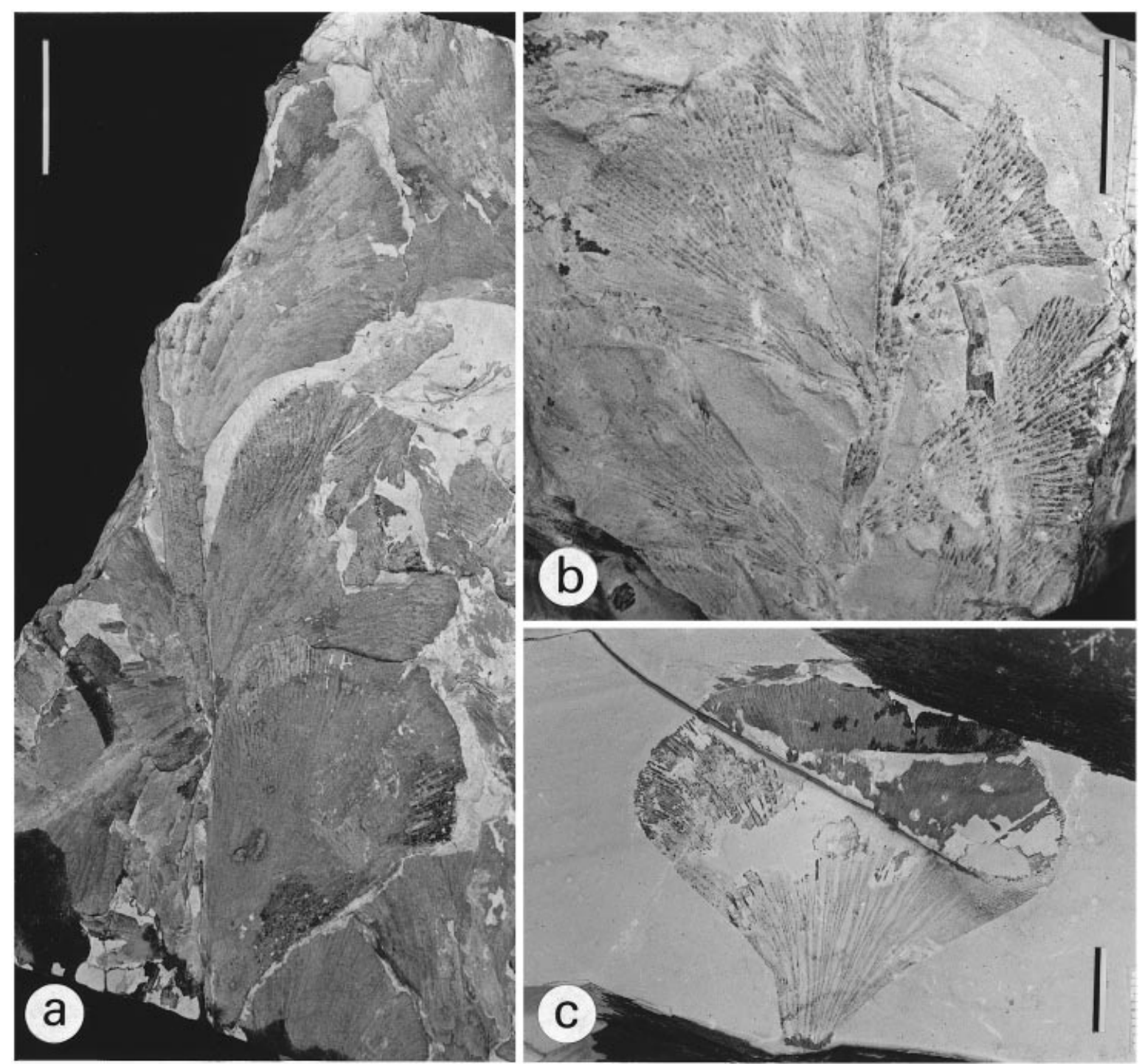

Figure 6. Plant fossils from Quebrada Potrero Rincón. (a, b) cf. Archaeopteris Dawson. (a) Three leaves attached to axis and a fragmentary fourth (lowest) also believed attached, CCHE-IX-86-026; (b) five leaves attached to axis, ICN-PI-0378-1; (c) leaf fossil, ICN-PI-0292-2. Scale bars $=10 \mathrm{~mm}$.

\section{Specimen no. ICN-PI-0378-1}

Figure 6b

This axis, of $2 \mathrm{~mm}$ width, bears five leaves of $22 \mathrm{~mm}$ maximum length in an apparent alternate arrangement. They are inserted at approximately $45^{\circ}$ on narrow bases, but enlarge to a maximum width of $20 \mathrm{~mm}$ distally. Proximal margins are more or less straight and the leaves probably entire. Venation is dichotomously branched.

Comparison and identity. These specimens from the upper fossiliferous horizon, with a number of entire leaves inserted upon axes with a transverse ornament can only, in the context of Devonian sediments, be attributed to the genus Archaeopteris Dawson. They are therefore believed to be the leafy branches of a large arborescent progymnosperm. No attached fertile parts are in evidence which would allow unambiguous assignment to this genus.

Delimitation of Archaeopteris species based on fragmentary specimens is neither well founded nor wise (Gensel \& Barnett-Lawrence, 1996). There is considerable polymorphism and variation in leaf size within individual fronds (Kenrick \& Fairon-Demaret, 1991) and presumably within branches and on individual trees.

Our Archaeopteris is most similar to A. halliana from North America and A. roemeriana from Belgium (the former synonymized with the latter by Kräusel \& Weyland (1941)) in terms of leaf morphology, venation and overlap of the leaves. However leaves of $A$. halliana were defined as less than $20 \mathrm{~mm}$ by Kräusel \& Weyland (although leaves 'slightly over $2 \mathrm{~cm}$ long' were included in the species by Gensel \& BarnettLawrence (1996), based on material from the Frasnian 
of Gaspé, Canada). The attached leaves are up to $33 \mathrm{~mm}$ in the Colombian specimens, and so may be more comparable to A. obtusa Lesquereux. However, with so few fragmentary, sterile specimens, any attempt to assign these fossils to a species is futile.

Archaeopteris is widespread in the sediments of Late Devonian age, known also from high and low latitudes of Gondwana (South Africa, Australia) as well as New York State, Ellesmere Island, western Europe (Laurentia), Siberia and China.

\section{Leafy fossils}

\section{Specimen no. MCH-019-e}

Material. Rain drop horizon, lower level of Lower Member of Cuche Formation, Quebrada Potrero Rincón.

Description. This fossil is an incomplete leaf, faintly preserved, of maximum length $63 \mathrm{~mm}$. At the most proximal preserved point it measures only $4 \mathrm{~mm}$ wide, $20 \mathrm{~mm}$ more distal it is $12 \mathrm{~mm}$ wide, but it widens quickly to a maximum preserved width of $43 \mathrm{~mm}$, it being flabelliform in outline. The leaf veins are indistinctly preserved and curve outwards towards the distal margins. A second specimen (unnumbered) in a slightly coarser red matrix suggests that the leaves were inserted acutely and possibly spirally upon an axis, but the axis itself is missing and the three leaves are more fragmentary than that described above. Both fossils are poorly and indistinctly preserved as impressions lacking organic carbon.

\section{Specimen no. ICN-PI-0292-2}

Figure 6c

Material. Locality 4, assemblage III.

Description. This flabelliform leaf has a minimum proximal width of $6 \mathrm{~mm}$ and a maximum width of $52 \mathrm{~mm}$ some $20 \mathrm{~mm}$ from the base. Its maximum length is $45 \mathrm{~mm}$. Veins dichotomise distally (basally they measure $0.15 \mathrm{~mm}$ to an occasional $0.3 \mathrm{~mm}$ ) and widen distally where they curve away from the midline of the leaf towards the distal lateral margins. The leaf is entire, as far as can be judged, with concave margins proximally and convex distally, and its width to length ratio is considerably higher than those discussed in the preceding paragraph.

Identity and comparisons. The isolated leafy fossils from the lower red beds are very large, comparable with the largest pinnules of the sterile type specimens of Archaeopteris obtusa (Lesquereux, 1880). Their morphology and insertion is comparable to other illustrated examples of $A$. obtusa from the Upper Devonian sediments of Gaspé (Cyclopteris obtusa of Dawson, 1882; Gensel \& Barnett-Lawrence, 1996).
Such leaves are often referred to Psygmophyllum or Flabellifolium (see e.g. Gensel \& Barnett-Lawrence, 1996). The specimen from locality 4 is better preserved but is of squatter outline. We do not feel compelled to assign generic or specific names to this material; rather its occurrence suggests the presence of Archaeopteristype plants in the Lower as well as Upper Member of the Cuche Formation.

\section{Stratigraphic implications}

In New York State, Colpodexylon is restricted to the Givetian and lowermost Frasnian deposits. It is also known from Venezuela, Vietnam, and south and northwestern China during the same time (Berry, 1997). Archaeopteris species with entire leaves are first found in lower Frasnian deposits of Gaspé, Canada (Gensel \& Barnett-Lawrence, 1996; McGregor, 1996) and continue at least to the latest part of the Devonian Period (Fairon-Demaret, 1986). Trimerophyte derivatives superficially similar to ours are known from Lower, Middle and lower Upper Devonian sediments and have less stratigraphic significance.

Devonian plant biostratigraphy is not yet an exact science (Edwards \& Berry, 1991; Edwards, FaironDemaret \& Berry, in press). However the cooccurrence of Colpodexylon and Archaeopteris in assemblage III suggests a Late Devonian (earliest Frasnian) age for the middle of the Upper Member of the Cuche Formation. The presence of large leaves near the base of the Lower Member suggests it is also of the same age. Archaeopteris and Colpodexylon cooccur in Livingstone Quarry, Oneonta Formation (lower Frasnian) in New York State (Banks, Grierson \& Bonamo, 1985).

\section{Comparison with other contemporaneous South American assemblages}

\section{6.a. Venezuela}

The most diverse, best known, Devonian floras of Middle and Late Devonian age in South America are those from the Campo Chico Formation in the Río Cachirí area of the Sierra de Perijá, northwestern Venezuela. The Lower Member of the Campo Chico Formation contains a diverse flora composed of zosterophylls (cf. Sawdonia; Serrulacaulis cf. furcatus, Berry \& Edwards, 1994), herbaceous lycopsids (Leclercqia cf. complexa, Berry, 1994; Haskinsia sagittata Edwards \& Benedetto, 1985; H. hastata Berry \& Edwards, 1996a; Colpodexylon cachiriense Edwards \& Benedetto, 1985; C. coloradoense, C. camptophyllum Berry \& Edwards, 1995; Gilboaphyton griersonii Berry \& Edwards, 1997), iridopteridaleans (Anapaulia moodyi Berry \& Edwards, 1996b; new genus), cladoxylopsids (Wattieza sp.), progymnosperms (Rellimia sp.), a possible rhyniopsid (with S-type vascular tissues), 
and various other as yet unclassified plants. These are believed to be of Givetian (late Middle Devonian) age (Berry, Casas \& Moody, 1993) but may be also of latest Eifelian or early Frasnian age.

Recently, in the Upper Member of the Campo Chico Formation, a more restricted flora has been discovered, composed predominantly of two species of Archaeopteris, one with large, entire, flabelliform leaves, and a second with smaller, more dissected leaves superficially similar to those of A. notosaria from South Africa (Anderson, Hiller \& Gess, 1995).

\section{6.b. Colombia}

A small florule of Middle Devonian age was reported from the Middle Devonian of Chitagá Canyon, near Pamplona, northeastern Colombia (Boinet et al. 1986). Three taxa were recognized. A single specimen of the herbaceous lycopsid Protolepidodendron sp. requires demonstration of leaf morphology before it can be correctly identified, yet the sections through the leaves illustrated suggest it could belong to Haskinsia or Leclercqia. A sterile axis of cf. Stockmansella langii has a prominent vascular strand and is superficially identical to the 'possible rhyniopsids' reported (above) from Venezuela. A leaf of $35 \mathrm{~mm}$ length attributed to Psygmophyllum cf. williamsonii is typical of disarticulated Archaeopteris. Some dichotomizing axes are also present.

\section{6.c. Elsewhere in South America}

Away from the northwestern corner of South America, Middle and Upper Devonian plant fossils are less well preserved, less diverse, and even less confidently dated.

In Argentina, lycopsids are common in sediments believed to be of Middle Devonian age, and are attributed to the genera Haplostigma and Malanzania (Gutierrez, 1996). These do not have well preserved complex leaf morphology which precludes their being placed in genera such as Haskinsia, Colpodexylon or Leclercqia. Frenguellia, a generic concept developed from fossils from widespread localities with little age constraint, demonstrates complex leaf morphology and adaxial sporangia on unmodified leaves, characters known only from Lower, Middle and lowest Upper Devonian lycopsids; however these plants are reported to be from the Lower Carboniferous (Arrondo, Cesari \& Gutierrez, 1991; Morel et al. 1993). Specimens attributed to the Middle Devonian cladoxylopsid Hyenia (Morel et al. 1993) are more likely to represent erect aerial axes rather than trailing rhizomes and therefore the sterile specimens cannot be identified, perhaps being of progymnosperm origin (Fairon-Demaret \& Berry, in press).

A few specimens have been attributed to lycopsids from the Devonian of Piauí State, Brazil (Kraüsel \&
Dolianiti, 1957). Protolepidodendron kegeli has preserved leaves which were reported to be similar to tuning forks. 'Archaeosigillaria' picosensis was a stem impression with characteristic stem-surface features. Lastly, Kraüsel \& Dolianiti reported stems superficially similar to lycopsids with randomly arranged 'leaf scars' under the name Palaeostigma sewardi. These last two taxa are also known from South Africa (Anderson \& Anderson, 1985; Chaloner et al. 1980).

\section{Geological context}

The two Colombian localities (Floresta, Pamplona) demonstrate the continuation of the flora known to have flourished in northwestern Venezuela during late Middle and earliest Late Devonian times some $600-700 \mathrm{~km}$ further southeast in present-day terms (Fig. 1). The Venezuelan flora, exceptional in its diversity, most clearly resembles that of New York State and western Europe. Some species are in common between New York and Venezuela (Gilboaphyton griersonii, Haskinsia sagittatalcollophylla, Leclercqia complexa, Serrulacaulis furcatus amongst those groups so far investigated in detail). There are also some similarities to Belgium (e.g. Wattieza sp., Serrulacaulis, Leclercqia). It is not possible yet to demonstrate such relationships with the less well preserved floras of Argentina and Brazil (the latter appearing to show at least slight affinity to South Africa). Although a disparity in vegetation is possible, this observation may be at least partly due to the paucity of the record in mid and southern South America.

The similarity of Devonian invertebrate faunas of the Sierra de Perijá and Colombia to those of the Eastern Americas Invertebrate Realm is more strongly defined (e.g. brachiopods: Benedetto, 1984; corals: Scrutton, 1973; Meyerhoff et al. 1996) and, because of higher numbers of localities and better geographical coverage, provides a better basis currently for palaeogeographical deliberation than plant megafossils.

There are quite different opinions about the origin and tectonic relationships of the north Andean provinces and the western pericratonic region of the Guyana Shield during Palaeozoic times. Both regions are now separated by a complex thrust fault system known as the Borde Llanero Fault System, Borde Llanero Suture or Guaicaramo-Yopal Fault System. Some previous authors have assumed that the Devonian deposits of northwestern South America have been deposited on the margins of the Gondwana supercontinent (Barrett, 1988; Benedetto, 1984; Berry, 1994) and are more or less in situ. Maze (1984) suggested, based on palaeomagnetic data, that area to the west of Lake Maracaibo might be allochthonous. Restrepo \& Toussaint (1988) considered that the Palaeozoic to Early Mesozoic history of the autochthonous block (pericratonic region: AUT in Fig. 1) is fundamentally different from that of the 
Eastern Andean Terrane immediately to the west (EAT in Fig. 1), and only Late Jurassic events are common to both blocks. Consequently, Restrepo \& Toussaint (1988) concluded that suturing occurred sometime during or before Jurassic times. Each of the three plant-bearing Devonian deposits discussed above, Sierra de Perijá (Venezuela), Pamplona and Floresta (Colombia), is within the Eastern Andean Terrane.

A quite similar scenario for tectonic development during Devonian times was presented by Forero (1990), who considered that the Borde Llanero Fault System represents the limit between two Early Palaeozoic provinces, the Guyana Shield (Gondwana) to the east and an allochthonous terrane (formerly a piece of the North American continent) to the west, the last comprising the Eastern Cordillera, the Magdalena Valley and the eastern part of the Central Cordillera. Forero (1990) postulated that both terranes were accreted during Late Silurian to Early Devonian times (Caledonian Orogenesis) as a consequence of the collision between North and South America (Gondwana). Consequently, the Devonian sediments of both regions should lie on a Precambrian to Early Palaeozoic basement, and the Devonian benthic-faunal records on the neighbouring sides of North and South America have to be very similar. In this context, Forero (1986) pointed out that during Late Devonian times (Frasnian-Famennian) faunal and lithofacial similarities suggest a close geographic relationship between the areas encompassed by the Devonian Old World Realm (North America, Europe and northern Africa).

An accretionary model resulting from progressive westward migration of subduction zones has been also proposed by McCourt, Aspden \& Brook (1984), who considered that during the ?Devonian a subduction zone existed oceanward of the Precambrian Guyana Shield, and that the Bolo Azul and the Rosario complexes of the Central Cordillera are remnants of the volcanic arc. The quartz-rich, low metamorphic grade Cajamarca Group (Nelson, 1957) might represent accumulation at the same time to the east of the arc. In this context, the Devonian sediments in the Eastern Cordillera should have been deposited more or less in situ. However, the expected Devonian dating of the Cajamarca Group and of the Bolo Azul and Rosario complexes remains speculative and their possible time relationships to the Devonian sediments of the Eastern Andean Terrane have to be proven.

Mojica \& Villarroel (1990) have postulated an in situ development of this region, taking into account that the Lower Palaeozoic of the western border of the Guyana Shield, the Llanos area, the Eastern Cordillera and the Magdalena Valley show a continuous, coherent lateral facies development that reflects an eastern located source area and sedimentation in a broad, shallow platform deepening westwards towards the present Central Cordillera, thus indicating that the whole region was part of one tectonic province or terrane. Moreover, the Lower Palaeozoic sediments of the Eastern Andean Terrane show no evidence of low grade metamorphism (Jiménez \& Caicedo, 1998) or of having been highly deformed (Mojica, Villarroel \& Macia, 1987) by any Palaeozoic orogenesis as supposed by those authors favouring an allochthonous origin.

The results obtained in this work indicate that the Late Devonian plants described here have closer relationships to those of the Laurussian continent than can yet be demonstrated for the Gondwana continent. However, the presence of typical Gondwanan elements (e.g. Antarctilamna) in newly discovered vertebrate assemblages associated with the plants from Colombia and Venezuela (Janvier \& Villarroel, 1998; G. C. Young, pers. comm.) suggest also a connection with the east part of the north Gondwana margin, probably in close proximity to or in contact with the Laurussian supercontinent. The origin of this disagreement is not yet clear. Possible future discoveries of additional Devonian localities across Gondwana may help in solving this problem.

\section{Conclusions}

(1) As indicated by the palaeontological results obtained in this work and that of Janvier \& Villarroel (1998), the sedimentary rocks representing the Devonian System in Colombia include not only the often mentioned shallow marine sequence of the Floresta Formation, but also fossil-bearing red beds of the Cuche Formation. The plant and vertebrate content indicates a Late Devonian (Frasnian) age for the whole Cuche Formation.

(2) The sedimentary record of the Upper Devonian in northwestern South America discussed here comprises a narrow northeast to southwest belt (600-700 km long), restricted to the north-central Eastern Cordillera of Colombia and the eastern flank of the Perijá Range. The above mentioned Upper Devonian belt has not been taken into account in relatively recent palaeogeographical reconstructions, e.g. Barrett (1988).

(3) The flora and fauna of the Cuche Formation and other Middle and Upper Devonian sediments from Colombia and Venezuela show closest similarity to those of eastern North America and western nonalpine Europe.

\footnotetext{
Acknowledgements. JM and $\mathrm{CV}$ are very grateful to those persons of the Universidad Nacional de La Plata who first established the importance of studying the plants of the Cuche Formation (especially Professors Bruno Petriella, Sergio Archangelsky and Oscar Arrondo) and encouraged us to conduct more detailed fieldwork and collect more specimens. CMB would like to thank the Geological Society, London (W. G. Fearnsides Fund) for supporting fieldwork in Colombia, and Professors M. Fairon-Demaret and P. Gensel for their helpful reviews of the manuscript.
} 


\section{References}

Anderson, J. M. \& Anderson, H. M. 1985. Prodromus of South Africa megafloras, Devonian to Lower Cretaceous. Rotterdam: Balkema, $400 \mathrm{pp}$.

Anderson, H. M., Hiller, N. \& Gess, R. W. 1995. Archaeopteris (Progymnospermopsida) from the Devonian of southern Africa. Botanical Journal of the Linnean Society 117, 305-20.

Arrondo, O., Cesari, S. N. \& Gutierrez, P. R. 1991. Frenguellia, a new genus of lycopods from the Early Carboniferous of Argentina. Review of Palaeobotany and Palynology 70, 187-97.

BANKs, H. P. 1944. A new Devonian lycopod genus from southeastern New York. American Journal of Botany 31, 649-59.

Banks, H. P., Grierson, J. D. \& Bonamo, P. B. 1985. The flora of the Catskill clastic wedge. Geological Society of America Special Paper 201, 125-41.

Banks, H. P., Leclerce, S. \& Hueber, F. M. 1975. Anatomy and morphology of Psilophyton dawsonii sp. n. from the late Lower Devonian of Quebec (Gaspé), and Ontario, Canada. Palaeontographica Americana 8, $77-127$.

Barrett, S. F. 1988. The Devonian System in Colombia. In Devonian of the World (eds N. J. McMillan, A. F. Embry and D. J. Glass), pp. 705-17. Canadian Society of Petroleum Geologists, Memoir no. 14.

BenedetTo, J.-L. 1984. Les Brachiopodes devoniens de la Sierra de Perijá (Venezuela). Biostratigraphie de Paléozoique (Brest) 1, 1-191.

BERRY, C. M. 1994. First record of the Devonian lycophyte Leclercqia from South America. Geological Magazine 131, 269-72.

BERRY, C. M. 1997. Diversity and distribution of Devonian herbaceous lycopsids. The Palaeobotanist 45, 209-16.

Berry, C. M., Casas, J. E. \& Moody, J. M. 1993. Diverse Devonian Plant Assemblages from Venezuela. Documents de la Laboratoire Géologique de Lyon 125, 29-42.

Berry, C. M. \& Edwards, D. 1994. New data on the morphology and anatomy of the Devonian zosterophyll Serrulacaulis Hueber and Banks from Venezuela. Review of Palaeobotany and Palynology 81, 141-50.

BERry, C. M. \& EdwardS, D. 1995. New species of the Devonian lycophyte Colpodexylon from the Devonian of Venezuela. Palaeontographica B 137, 59-74.

BERRY, C. M. \& EdwARds, D. 1996a. The herbaceous lycophyte genus Haskinsia Grierson and Banks from the Devonian of western Venezuela, with observations on the leaf morphology and fertile specimens. Botanical Journal of the Linnean Society 122, 103-22.

Berry, C. M. \& EDwARds, D. 1996b. Anapaulia moodyi gen et sp nov, a probable iridopteridalean compression fossil from the Devonian of Venezuela. Review of Palaeobotany and Palynology 93, 127-45.

Berry, C. M. \& Edwards, D. 1997. A new species of the lycopsid Gilboaphyton Arnold from the Devonian of Venezuela and New York State with a revision of the closely related genus Archaeosigillaria Kidston. Review of Palaeobotany and Palynology 96, 47-70.

Boinet, T., Babin, C., Bourgois, J., Broutin, J., Lardeux, H., Pons, D. \& Racheboeuf, P. 1986. Les grandes étapes de l'évolution paléozoïque du Massif de Santander (Andes de Colombie): signification de la discordance du Dévonien moyen. Comptes Rendus de l'Academie des Sciences. Serie II 303, 707-12.
Botero, C. 1950. Reconocimiento Geológico del área comprehendida por los municipos de Bélen, Cerinza, Corrales, Floresta, Nobsa y Santa Rosa de Viterbo, Depto. Boyacá. Compilacio de los Estudios Geologicos Oficiales en Colombia. Instituto Geologico Nacional (Colombia) 8, 245-311.

CAster, K. E. 1939. A Devonian fauna from Colombia. Bulletins of American Paleontology 24, 1-219.

Cediel, F. 1969. Geología del Macizo de Floresta. Memorias Primer Congreso Colombiano de Geología, $17-20$.

Chaloner, W. G., Forey, P. L., Gardiner, B. G., Hill, A. J. \& Young, V. T. 1980. Devonian fish and plants from the Bokkeveld Series of South Africa. Annals of the South African Museum 81, 127-57.

DAwson, J. W. 1882. The fossil plants of the Erian (Devonian) and Upper Silurian Formations of Canada, part II. Montreal: Geological Survey of Canada, pp. $95-142$.

EDwARds, D. \& Benedetto, J. L. 1985. Two new species of herbaceous lycopods from the Devonian of Venezuela with comments on their taphonomy. Palaeontology 28, 599-618.

EdwARds, D. \& BERry, C. M. 1991. Silurian and Devonian. In Plant fossils in geological investigations: the Palaeozoic (ed. C.J. Cleal), pp. 117-53. Ellis Horwood Series in Applied Geology.

Edwards, D., Fairon-Demaret, M. \& Berry, C. M. in press. Plant megafossils in Devonian Stratigraphy: a progress report. Courier Forschungsinstitut Senkenberg.

FAIron-DemareT, M. 1986. Some uppermost Devonian megafloras: a stratigraphic review. Annales de la Société géologique de Belgique T109, 43-8.

FAiron-Demaret, M. \& Berry, C. M. in press. A reconsideration of Hyenia elegans Kräusel \& Weyland and Hyenia 'complexa' Leclercq - two Middle Devonian cladoxylopsids from western Europe. International Journal of Plant Sciences.

Fairon-Demaret, M., Hilton, J. \& Berry, C. M. 1999. Morphology - surface preparation of fossils. In Fossil Plants and Spores: modern techniques (eds T. P. Jones and N. P. Rowe), pp. 33-5. London: Geological Society of London.

Forero, A. 1986. Remanentes de la provincia paleogeográfica Frasniano-Fameniana del viejo mundo en Los Andes Septentrionales. Geología Norandina 10, 35-8.

Forero, A. 1990. The basement of the Eastern Cordillera, Colombia: An allochthonous terrane in northwestern South America. Journal of South American Earth Sciences 3, 141-51.

Forero, A. 1991. Distribución de las rocas del Devónico en los Andes Colombianos. Revista Técnica de Yacimientos Petroliferos Fiscales Bolivianos 12, 101-11.

Gensel, P. G. \& Barnett-Lawrence, M. 1996. Plant megafossils from the Escuminac Formation. In Devonian fishes and plants of Miguasha, Quebec (eds H.-P. Schultze and R. Cloutier), pp. 79-90. München: Friedrich Pfeil, 374 pp.

Grösser, J. \& Prössel, K. F. 1994. Palynologische Untersuchungen der Devonbasis in Floresta Massiv, Ostkordillere, Kolumbien, Südamerika. Giessener Geologische Schriften 51, 105-21.

Grierson, J. D. \& BANKS, H. P. 1963. Lycopods of the Devonian of New York State. Palaeontographica Americana 4, 220-95.

Gutierrez, P. R. 1996. Revisión de las licópsidas de la 
Argentina. 2. Malanzania Archangelsky, Azcuy et Wagner y Haplostigma Seward; con notas sobre Cyclostigma Haughton. Ameghiniana 33, 127-44.

Hettner, A. 1892. Die Kordillere von Bogotá. Petermanns Mitteilungen Ergaenzungsheft 22, 131pp.

HøEG, O. A. 1952. Psilophytites, a new form genus of Devonian plants. Palaeobotanist 1 (Birbal Sahni Memorial Volume), 212-14

Janvier, P. \& Villarroel, C. 1998. Los peces Devónicos del Macizo de Floresta (Boyacá, Colombia). Consideraciones taxonómicas, bioestratigráficas biogeográficas y ambientales. Geología Colombiana 23, 3-19.

JimÉnez, D. M. \& CAiCedo J. C. 1998. La Formación El Hígado una pieza importante en el rompecabezas del Paleozoico Inferior de Colombia. Actas X Congreso Latinoamericano de Geología y VI Congreso Nacional de Geología Económica I, 25.

Kenrick, P. \& FAiron-Demaret, M. 1991. Archaeopteris roemeriana (Göppert) sensu Stockmans, 1948 from the Upper Famennian of Belgium: anatomy and leaf polymorphism. Bulletin de l'Institute des Sciences Naturelles de Belgique, Sciences de la Terre 61, 179-95.

KräUSEl, R. \& Dolianiti, E. 1957. Restos vegetais das Camadas Picos, Devoniano Inferior do Piaui. Minestério da Agricultura, Departamento Nacional da Produção Mineral, Divisão de Geologia e Mineralogia, Boletim 173, 7-19.

KräUSEl, R. \& Weyland, H. 1941. Pflanzenreste aus dem Devon von Nord-Amerika. Palaeontographica 86B, 1-78.

Lesquereux, L. 1880. Description of the Coal Flora of the Carboniferous Formation in Pennsylvania and throughout the United States. Second Geological Survey Pennsylvania, Report Progress 1, 1-254.

Li CHENG-SEN. 1990. Minarodendron cathaysiense (gen. et comb. nov.), a lycopod from the late Middle Devonian of Yunnan, China. Palaeontographica 220B, 97-117.

Matten, L. C. 1992. Studies on Devonian plants from New York State: Stenokoleos holmesii n. sp. from the Cairo flora (Givetian) with an alternative model for lyginopterid seed fern evolution. Courier Forschungsinstitut Senckenberg 147, 75-85.

Maze, W. B. 1984. Jurassic La Quinta Formation in the Sierra de Perijá, northwestern Venezuela: Geology and tectonic environment of red beds and volcanic rocks. In The Caribbean-South American Plate Boundary and Regional Tectonics (eds W. E Bonini, R. B. Hargraves and R. Shagam), pp. 263-82. Geological Society of America Memoir no. 162.

McCourt, W. J., Aspden, J. A. \& Brook, M. 1984. New geological and geochronological data from the Colombian Andes: continental growth by multiple accretion. Journal of the Geological Society of London 141, 831-45.

McGregor, D. C. 1996. Spores of the Escuminac Formation. Plant megafossils from the Escuminac Formation. In Devonian fishes and plants of Miguasha, Quebec (eds H.-P. Schultze and R. Cloutier), pp. 91-102. München: Friedrich Pfeil, 374 pp.

Meyerhoff, A. A., Boucot, A. J., Meyerhoff Hull, D. \& Dickins, J. M. 1996. Phanerozoic faunal and floral realms of the earth: the intercalary relations of the Malvinokaffric and Gondwana faunal realms with the Tethyan Faunal Realm. Geological Society of America Memoir no. 189, 69 pp.

Mojica, J. \& Villarroel, C. 1984. Contribución al conocimiento de las unidades Paleozoicas del area de Floresta (Cordillera Oriental Colombiana; Departamento de Boyacá) y en especial al de la Formacion Cuche. Geología Colombiana 13, 55-80.

Mojica, J. \& Villarroel, C. 1990. Sobre la distribución y facies del Paleozoico Inferior sedimentario en el extremo NW de Suramérica. Geología Colombiana 17, 219-26.

Mojica, J., Villarroel, C. \& Macia, C. 1987. Nuevos afloramientos fosilíferos del Ordovícico Medio (Fm. El Hígado) al oeste de Tarqui, Valle Superior del Magdalena (Huila, Colombia). Geología Colombiana 16, 95-7.

Morales, P. A. 1965. A contribution to the knowledge of the Devonian faunas of Colombia. Boletin de Geología, Universidad Industrial de Santander 19, 51-110.

Morel, E., Cingolani, C., Varela, R. \& Zuñiga, A. 1993. Devonian and Lower Carboniferous plant remains from the northern Precordillera, La Rioja Province, Argentina. XII Congrès International de la Stratigraphie et Géologie du Carbonifère et Permien, Buenos Aires, 1991, Comptes Rendus 2, 127-40. Buenos Aires.

Morel, E., Edwards, D. \& IÑigez Rodriguez, M. 1995. The first record of Cooksonia from South America in Silurian rocks of Bolivia. Geological Magazine 132, 449-52.

Nelson, H. W. 1957. Contribution to the Geology of the Central and Western Cordillera of Colombia in the sector between Ibagué and Cali. Leidse Geologische Mededelingen 22, 1-76.

Obrhel, J. 1959. Neue Pflanzenfunde in den SbrskoSchichten (Mitteldevon). Vestnik Ustred Ustavu Geol Svazek 34, 384-9.

Obrhel, J. 1961. Die Flora der Srbsko-Schichten (Givet) des mittelböhmischen Devons. Sbornik Ustred Ustavu Geol Svazek 26, 7-46.

Olsson, A. A. \& CAster, K. E. 1939. Part I: General Considerations. Bulletins of American Paleontology 24, 9-11.

RABE, E. 1977. Zur Stratigraphie des ostandinen Raumes von Kolumbien. Giessener Geologische Schriften 11, $1-223$.

Restrepo, J. J. \& Toussaint, J. 1988. Terranes and continental accretion in the Colombian Andes. Episodes 11, 189-93.

Royo y Gómez, J. 1942. Fósiles devónicos de Floresta (Departamento de Boyacá). Compilacio de los Estudios Geologicos Oficiales en Colombia. Instituto Geologico Nacional (Colombia) 5, 388-95.

SChweitzer, H.-J. \& CAI, C.-Y. 1987. Beitrage zur Mittledevon-flora Sudchinas. Palaeontographica 207B, $1-109$.

SCRUtTON, C. T. 1973. Palaeozoic coral faunas from Venezuela, II: Devonian and Carboniferous corals from the Sierra de Perijá. Bulletin of the British Museum of Natural History (Geology) 23 (4), 223-81. 